\title{
PERANCANGAN SISTEM INFORMASI PENJUALAN ONLINE
}

\author{
Sri Rezeki Candra Nursari ${ }^{1}$ \\ Yossela Immanuel ${ }^{2}$ \\ ${ }_{1,2}^{1}$ Dosen Universitas Pancasila \\ Email: sri.rezeki.candra.n@univpancasila.ac.id, yosselaJuve7@yahoo.co.id
}

Diterima: 3 Januari 2018/ Disetujui : 22 Januari 2018

\begin{abstract}
Internet technology has proved to be one of the effective and efficient information media in the dissemination of information that can be accessed by anyone, anytime and anywhere. Internet technology has a tremendous effect on commerce or business. Only from home or office space, potential buyers can view the products on the computer screen, access the information, order and pay with the available options. Potential buyers can save time and money because they do not need to come to the store or place of transactions so that from their seats can make a decision quickly. Online transactions can connect sellers and potential buyers directly without being limited by space and time. That means online sales transactions have potential buyers from all over the world. In addition, the company's development is considered a bit slow. Therefore designed an online sales system by using web or internet media with the aim to minimize sales process time with the aim to increase sales volume so that company earnings can increase. In this study the authors use waterfall and observation methods. In the implementation is displayed login and registration process, inputting: product data, product ordering, sales, payments, complaints, testimonials. It can be concluded that this system get information and reports easily. This system also allows consumers to make purchases of desired products. Controlling in recording and data security can be handled properly because each user has their respective passwords and given a menu in accordance with the process to be executed. Website visitors who do not register as consumers, can still see the products that are sold and also testimonials that have been made by consumers
\end{abstract}

Keywords: Online Sales, Complaints, Testimonials

\begin{abstract}
ABSTRAKSI
Teknologi internet sudah terbukti merupakan salah satu media informasi yang efektif dan efisien dalam penyebaran informasi yang dapat diakses oleh siapa saja, kapan saja dan dimana saja. Teknologi internet mempunyai efek yang sangat besar pada perdagangan atau bisnis. Hanya dari rumah atau ruang kantor, calon pembeli dapat melihat produk-produk pada layar komputer, mengakses informasinya, memesan dan membayar dengan pilihan yang tersedia. Calon pembeli dapat menghemat waktu dan biaya karena tidak perlu datang ke toko atau tempat transaksi sehingga dari tempat duduk mereka dapat mengambil keputusan dengan cepat. Transaksi secara online dapat menghubungkan antara penjual dan calon pembeli secara langsung tanpa dibatasi oleh suatu ruang dan waktu. Itu berarti transaksi penjualan secara online mempunyai calon pembeli yang potensial dari seluruh dunia. Selain itu perkembangan perusahaan terasa dinilai agak lambat. Oleh karena itu dirancang suatu sistem penjualan secara online dengan menggunakan media web atau internet dengan tujuan untuk meminimalkan waktu proses penjualan dengan tujuan dapat meningkatkan volume penjualan sehingga pendapatan perusahaan dapat meningkat. Dalam penelitian ini penulis menggunakan metode waterfall dan observasi. Pada implementasi ditampilkan proses login dan registrasi, penginputan : data produk, pemesanan produk, penjualan, pembayaran, komplain, testimonial. Dapat disimpulkan bahwa sistem ini mendapatkan informasi dan laporan dengan mudah. Sistem ini juga memudahkan konsumen untuk melakukan pembelian produk yang diinginkan. Pengontrolan dalam pencatatan dan keamanan data dapat ditangani dengan baik karena setiap user mempunyai password masing-masing dan diberikan menu yang sesuai dengan proses yang akan
\end{abstract}


dijalankan. Pengunjung website yang tidak mendaftar sebagai konsumen, masih dapat melihat produk yang di jual dan juga testimonial yang telah di buat oleh konsumen.

Kata Kunci : Penjualan Online, Komplain, Testimonial

\section{PENDAHULUAN}

Perkembangan bidang teknik informatika saat ini memungkinkan semua bidang kehidupan manusia dapat semakin ringan dikerjakan dengan bantuan komputer. Terlebih dengan ada nya jaringan internet yang dapat di akses dimana dan kapan pun. Dapat di manfaatkan oleh bisnis. Demikian halnya dengan jual-beli barang atau jasa yang dapat dilakukan secara online. Dengan menggunakan sebuah website penjualan, produk yang di jual dapat di lihat dengan mudah, dimana pun, dan kapan pun dengan bantuan computer dan jaringan internet.

Bidang usaha perdagangan sebagai penyedia barang atau jual beli barang, sering mengalami kesulitan untuk menginformasikan produk/barangnya, juga sering terjadi komplain karena barang yang dibeli serta diterima oleh konsumen/pelanggan tidak sesuai yang diinginkan dan atau rusak, sering juga pada proses pemesanan dan penerimaan barang waktu yang dibutuhkan oleh konsumen/ pelanggan berbeda-beda tidak sesuai dengan urutan sipemesan dan pada proses pembayaran sering terjadi ketidak sesuaian data yang terima dengan proses pembayaran melalui bank.

Dengan menggunakan sebuah website penjualan, produk yang di jual dapat di lihat dengan mudah, dimana pun, dan kapan pun dengan bantuan komputer dan jaringan internet.

\section{PERMASALAHAN}

Tujuan dari perancangan sistem informasi ini adalah untuk membangun suatu aplikasi penjualan online agar konsumen dapat melihat produk dan bertransaksi tanpa harus datang ke toko. Berdasarkan latar belakang di atas maka informasi penjualan OnLine dapat diuraikan beberapa masalah :

1. Seringnya terjadi ketidak terkinian informasi produk/barang yang dijual.

2. Seringnya terjadi komplain, karena barang yang dibeli dan diterima oleh konsumen/pelanggan tidak sesuai yang diinginkan dan atau rusak

3. Sering terjadinya ketidaksesuain antara laporan penjualan dengan barang yang masih tersedia

4. Pada proses pemesanan dan penerimaan barang waktu yang dibutuhkan oleh konsumen/pelanggan berbeda-beda, tidak sesuai dengan urutan sipemesan

5. Pada proses pembayaran, sering terjadi ketidak sesuaian data yang terima dengan proses pembayaran melalui bank

6. Pada proses pembuatan laporan, tidak rutin dibuat

Dalam aplikasi penjualan online terdapat 4 (empat) modul yaitu:

1. Menu produk yang dapat melakukan transaksi pembelian produk sesuai yang yang diinginkan.

2. Menu testimonial dimana user/konsumen dapat memberikan komentar terdapat produk yang ditawarkan

3. Menu FAQ adalah menampilkan pertanyaan dan jawaban apa saja yang berkaitan dengan proses penjualan produk, .

4. Menu About Us adalah menampilkan informasi tentang perusahaan.

\section{METODOLOGI}

\section{Tahap Pengumpulan Data}

a. Metode Pengamatan/Observasi

Pada tahap ini dilakukan dengan mengamati proses penjualan yang dilakukan secara online serta kendala-kendala yang sering terjadi. 


\section{b. Studi Pustaka}

Pada tahap ini dilakukan kajian terhadap buku-buku referensi dan literatur-literatur untuk memperoleh pengertian dan teori-teori dasar yang berhubungan dengan pokok masalah.

\section{Tahap Pengolahan Data}

a. Analisa desain

Pengolahan data dilakukan dengan cara mengelompokkan dan mengidentifikasi data dan informasi yang dibutuhkan serta mengkaji keterkaitan antara data dan informasi tersebut untuk diterapkan pada sistem yang akan dirancang atau di bangun. Adapun Pendekatan yang dipakai dalam perancangan sistem informasi penjualan online adalah dengan pendekatan terstruktur menggunakan tool-tool antara lain DFD (Data Flow Diagram), Kamus Data, Relasi Tabel, ERD (Entity Relation Diagram) dan Struktur Chart. Pada tahap analisis penulis menggunakan metode weterfall yang merupakan metode pengembangan perangkat lunak yang secara umum dilakukan dengan melalui beberapa tahapan penelitian yaitu:

- Analisis dan Definisi

- Perancangan Sistem

- Implementasi dan Pengujian

- Integrasi dan pengujian sistem

- Operasi dan pemeliharaan

b. Implementasi

Model dan rancangan aplikasi yang telah dibuat diimplementasikan dengan menggunakan bahasa pemrograman PHP5 dan menggunakan database MySql.

\section{SISTEM INFORMASI, BISNIS, PENJUALAN}

\section{Definisi Sistem Informasi}

Menurut Alter sistem informasi adalah kombinasi antara prosedur kerja informasi, orang dan teknologi informasi yang di organisasikan untuk mencapai tujuan. Menurut Turban, McLean, dan Wetherbe Sistem informasi adalah sebuah sistem informasi yang mempunyai fungsi mengumpulkan, memproses, menyimpan, menganalisis, dan menyebarkan informasi untuk tujuan yang spesifik. Dengan demikian dapat disimpulkan bahwa Sistem Informasi adalah teknologi informasi untuk mendukung operasi dan manajemen yang di butuhkan dalam mencapai tujuan organisasi.

\section{Definisi Bisnis}

Bisnis adalah suatu organisasi yang menjual barang atau jasa kepada konsumen atau bisnis lainnya, untuk mendapatkan laba. Secara historis kata bisnis dari bahasa Inggris business, dari kata dasar busy yang berarti "sibuk" dalam konteks individu, komunitas, ataupun masyarakat. Dalam artian, sibuk mengerjakan aktivitas dan pekerjaan yang mendatangkan keuntungan. Dalam ekonomi kapitalis, dimana kebanyakan bisnis dimiliki oleh pihak swasta, bisnis dibentuk untuk mendapatkan profit dan meningkatkan kemakmuran para pemiliknya. Pemilik dan operator dari sebuah bisnis mendapatkan imbalan sesuai dengan waktu, usaha, atau kapital yang mereka berikan.

Namun tidak semua bisnis mengejar keuntungan seperti ini, misalnya bisnis koperatif yang bertujuan meningkatkan kesejahteraan semua anggotanya atau institusi pemerintah yang bertujuan meningkatkan kesejahteraan rakyat. Model bisnis seperti ini kontras dengan sistem sosialistik, dimana bisnis besar kebanyakan dimiliki oleh pemerintah, masyarakat umum, atau serikat pekerja

\section{Penjualan}

Berkembangnya usaha-usaha perdagangan yang sangat pesat pada saat ini menjadikan informasi sebagai hal yang sangat penting peranannya dalam menunjang jalannya operasi-operasi demi tercapainya tujuan perusahaan. Jenis penjualan terdiri dari :

a. Penjualan langsung (direct response marketing / hardsell). Para pemasar melakukan pemasaran langsung untuk meningkatkan produktivitas satuan penjual-an. Selain itu perusahaan juga berupaya untuk menggantikan unit - unit penjualan berbasis pos dan telepon untuk mengurangi biaya penjualan lapangan 
b. Penjualan pribadi (personal selling). Seorang pemasar akan menawarkan produknya secara langsung dengan cara tatap muka

c. Penjualan tidak langsung.

Merupakan startegi untuk mempromosikan suatu produk atau jasa dapat ditemui dalam bentuk iklan, humas via internet secara tidak langsung

d. Penjualan partaian (merchandising) dan titik pembelian (point of purchase). Titik pembelian (Point-of-Purchase (P-O-P)) adalah kegiatan untuk menampilkan produk di tempat-tempat strategis di sebuah toko dengan tujuan untuk menarik perhatian konsumen terhadap merek tersebut.

e. Penjualan OnLine. Pemasaran secara online dilakukan melalui system computer online interaktif yang menghubungkan pelanggan dengan penjual secara elektronik

Bentuk-Bentuk Pemasaran Langsung Didalam pemasaran langsung dapat dilakukan dengan berbagai cara, yaitu seperti :

- Pemasaran tatap muka

- Pemasaran jarak jauh

- Pemasaran melalui surat langsung (faks, e-mail, voice mail)

- Pemasaran melalui catalog (merupakan pemasaran langsung melalui catalog cetak, video, elektronik yang dikirim kepada pelanggan pilihan (disediakan di toko dan dipresentasikan secara online))

- Pemasaran melalui televise yang menghasilkan tanggapan langsung Pemasangan iklan tanggapan langsung (direct response advertising) Saluran belanja dari rumah (home shopping channel)

\section{DESAIN APLIKASI}

\section{Arsitektur Perangkat Lunak}

Secara umum arsitektur perangkat lunak dapat digambarkan dengan perancangan sistem dengan menganalisa input, aliran data, output seperti dibawah ini: 


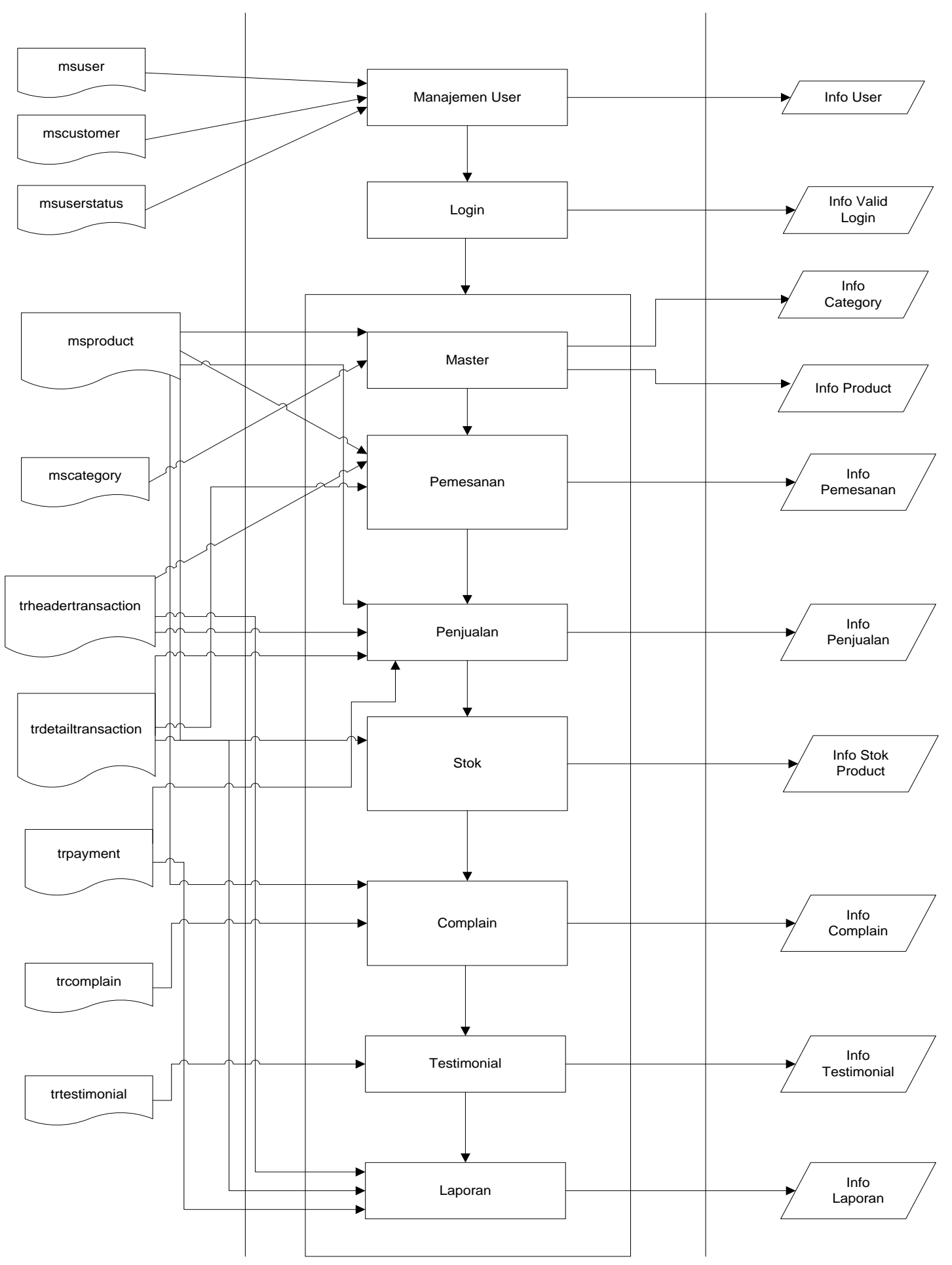

Gambar 1. Arsitektur Perangkat Lunak

\section{Diagram Konteks}

Berikut ini adalah diagram konteks dari aplikasi penjualan OnLine : 


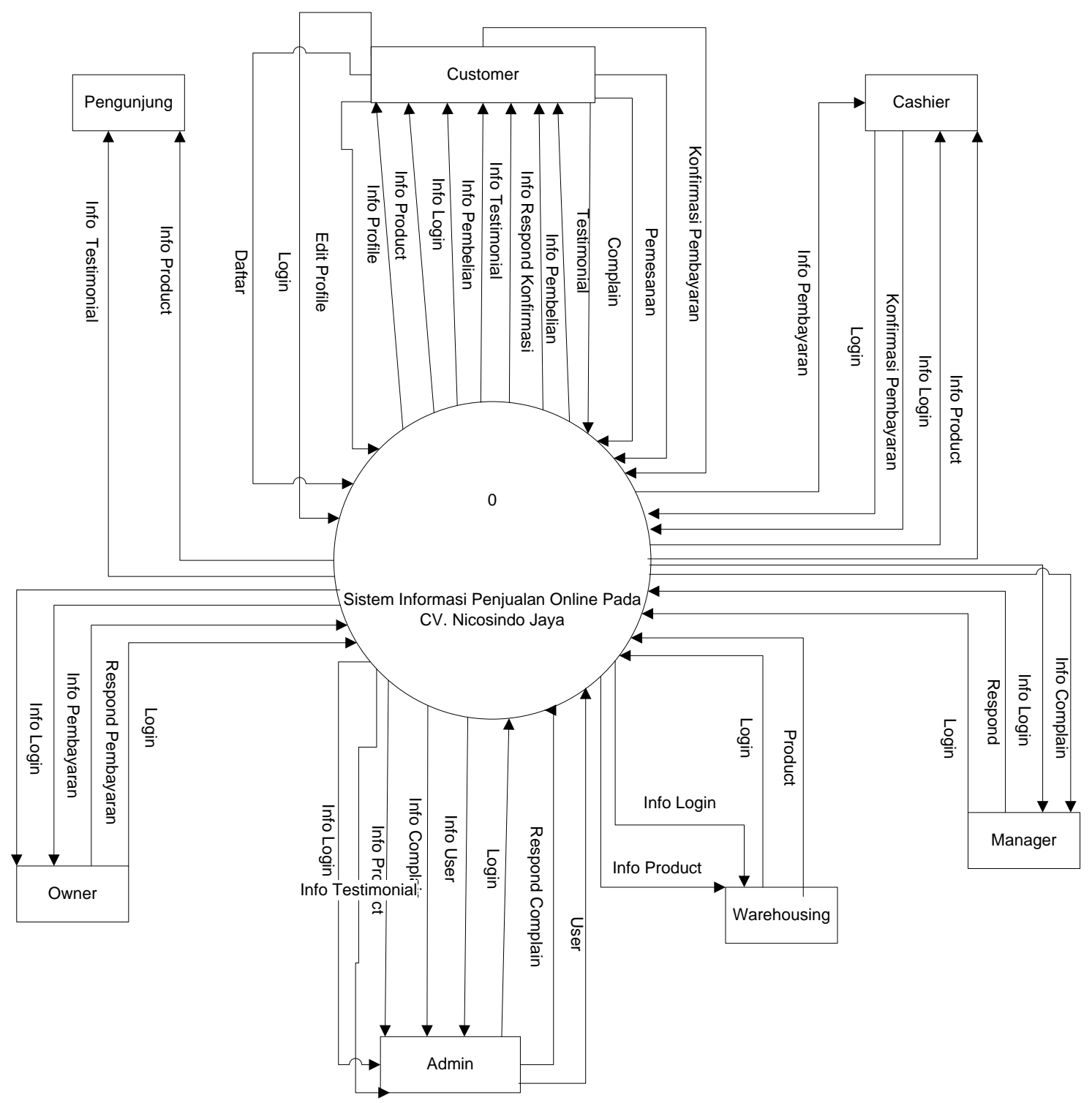

Gambar 2. Diagram Konteks

\section{Data Flow Diagram (DFD) Level 0}

Berikut ini adalah DFD level 0 yang merupakan turunan dari diagram konteks untuk dekomposisi proses yang disebut subproses dan merupakan uraian dari proses yang ada didalam sistem. 


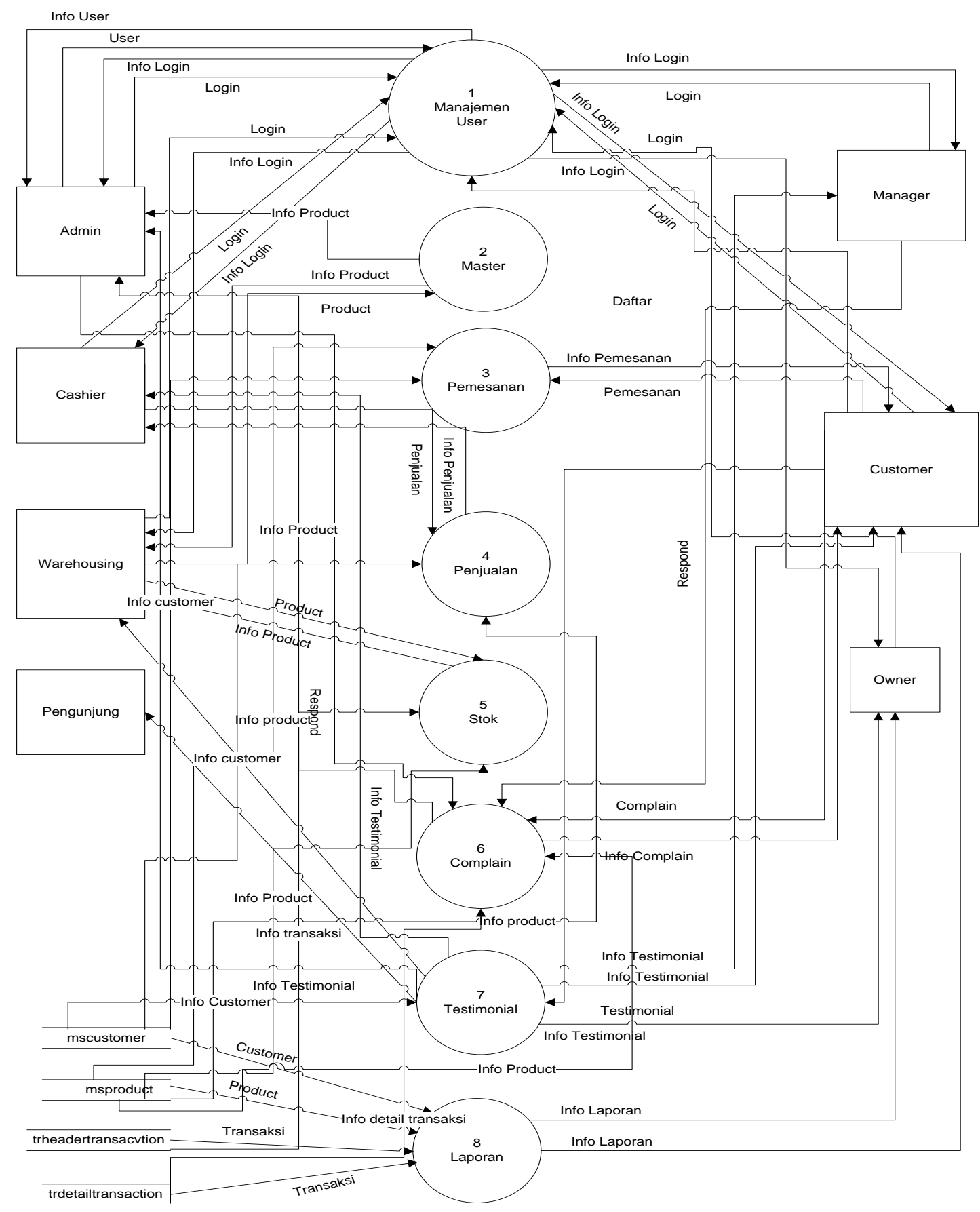

Gambar 3. DFD Level 0 


\section{Perancangan Basis Data}

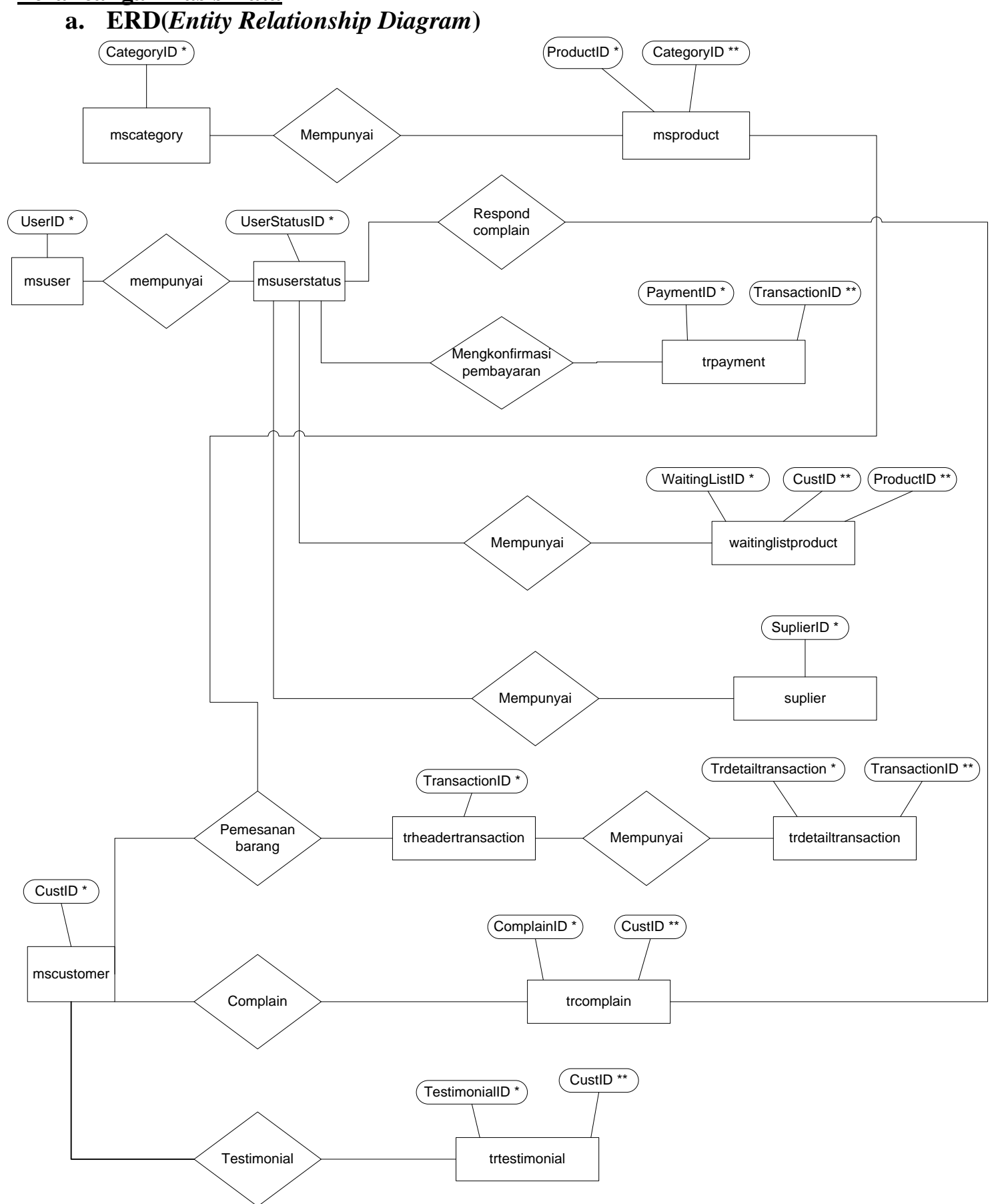

Gambar 9 Entity Relationship Diagram 


\section{b. Relasi Antar Tabel}

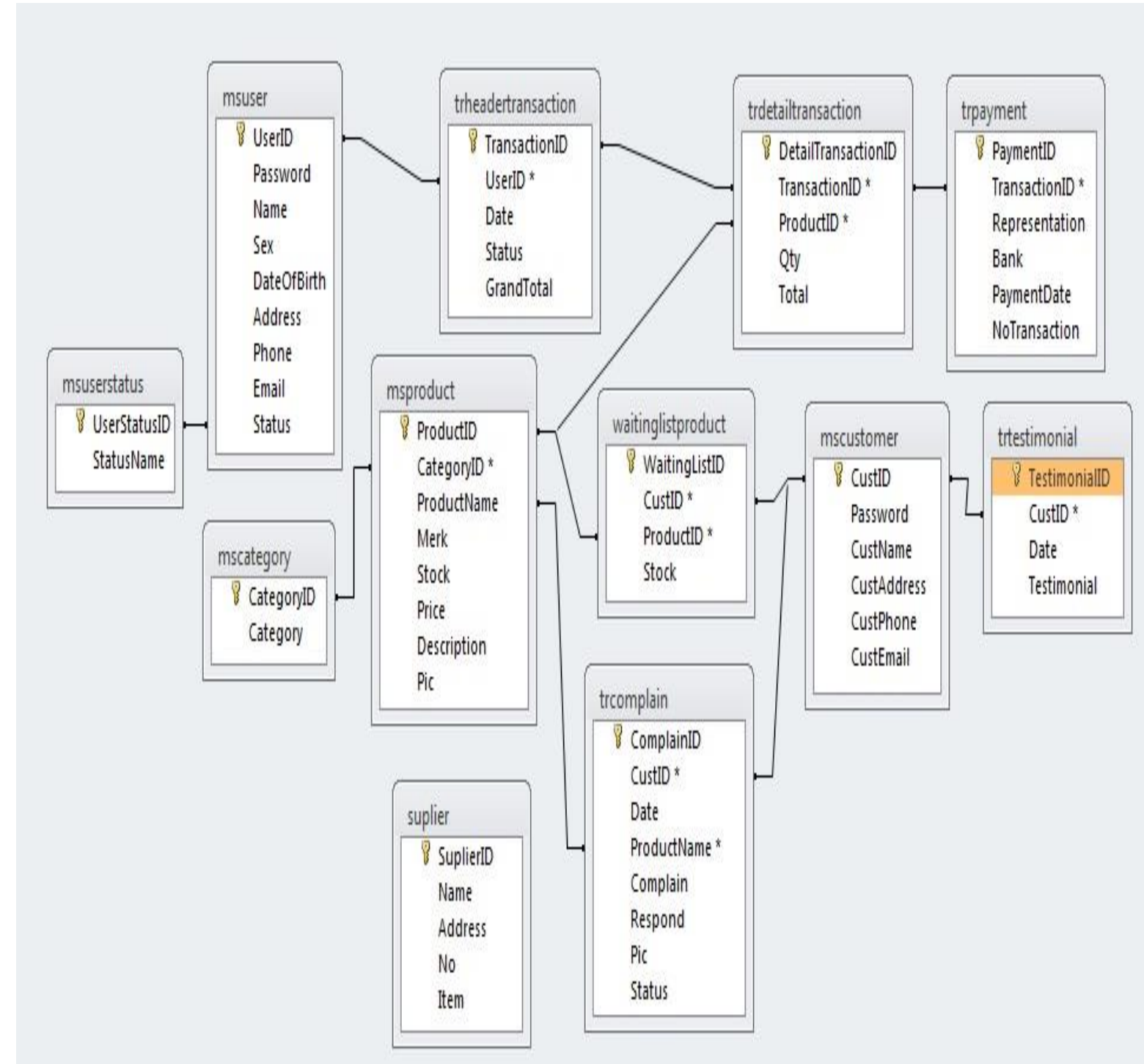

Gambar 10. Relasi Tabel

\section{IMPLEMENTASI PROGRAM}

\section{Tampilan Menu Utama}

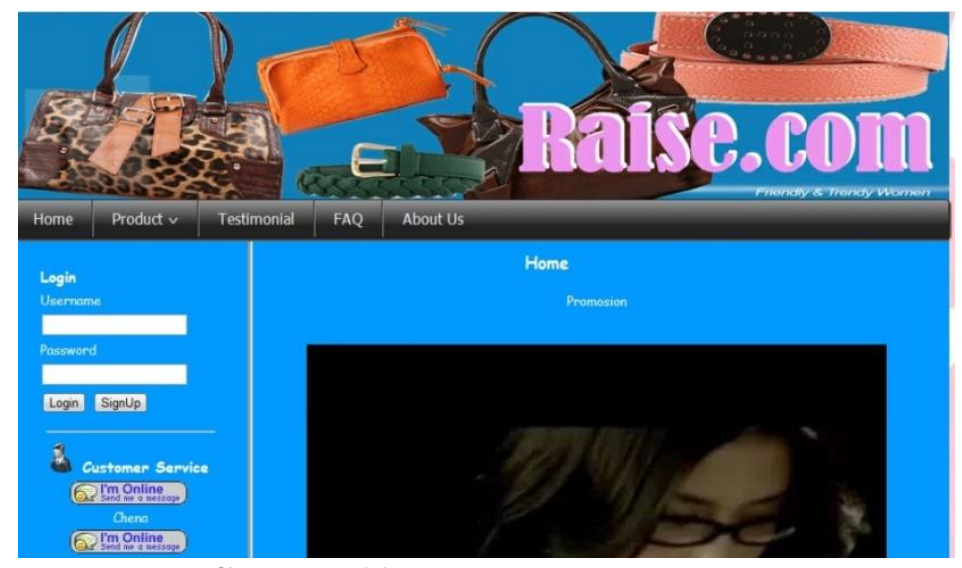

Gambar 11. Tampilan Menu Utama 


\section{Tampilan Proses Login dan Registrasi}

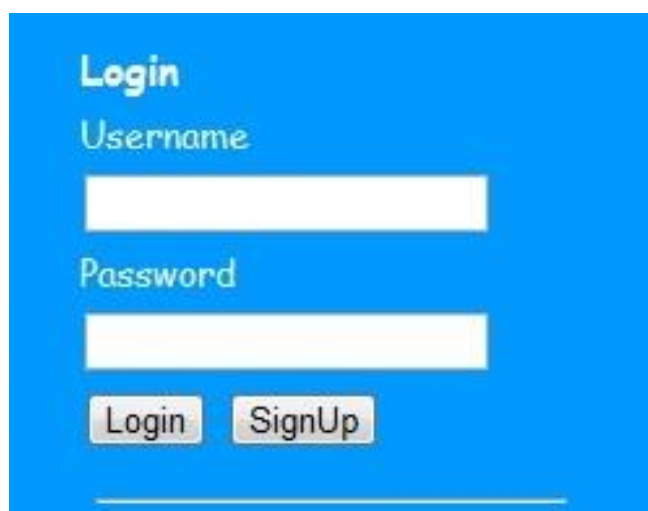

Gambar 12. Login

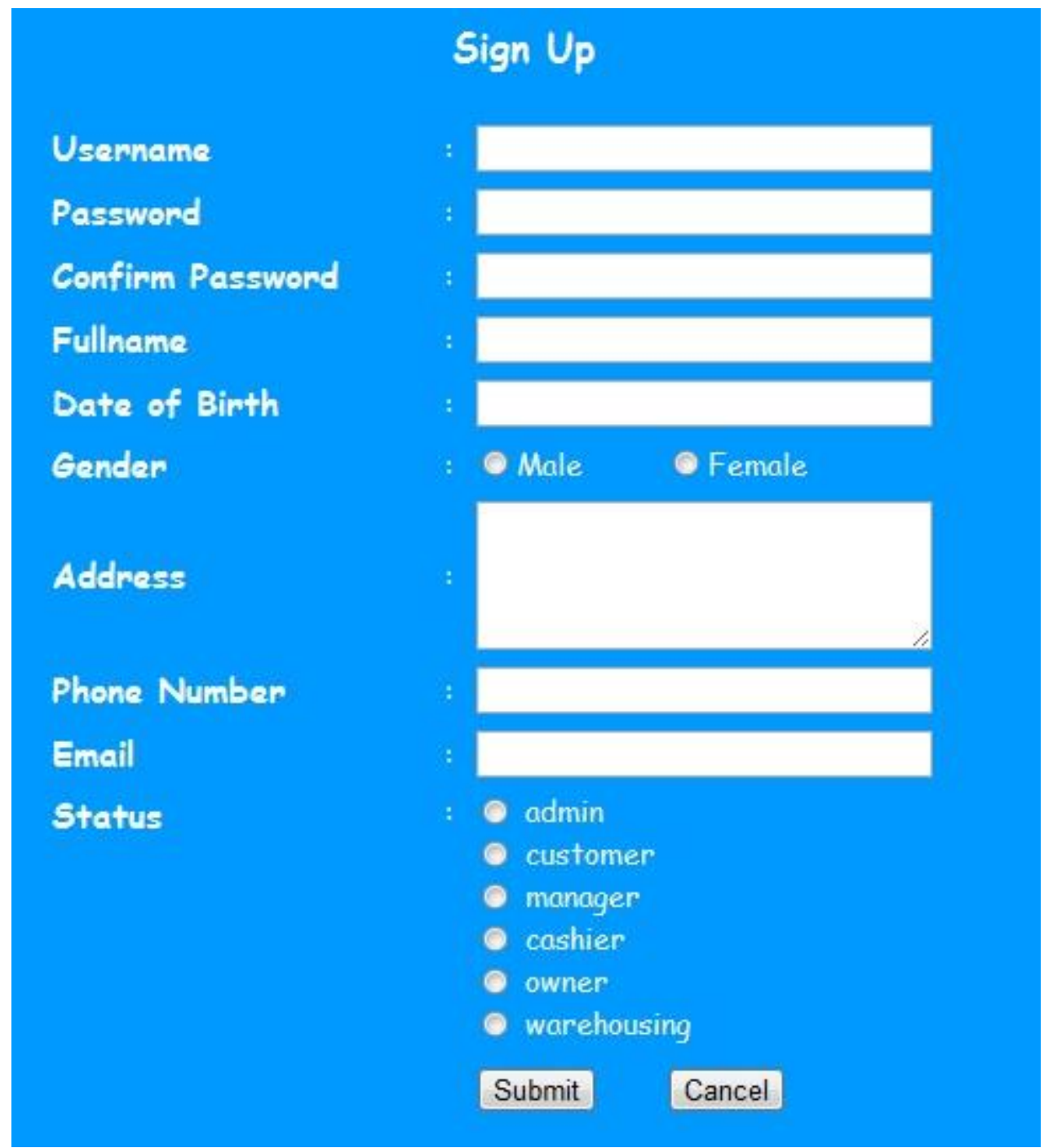

Gambar 13. Registrasi 


\section{Tampilan Proses Input Data Produk}

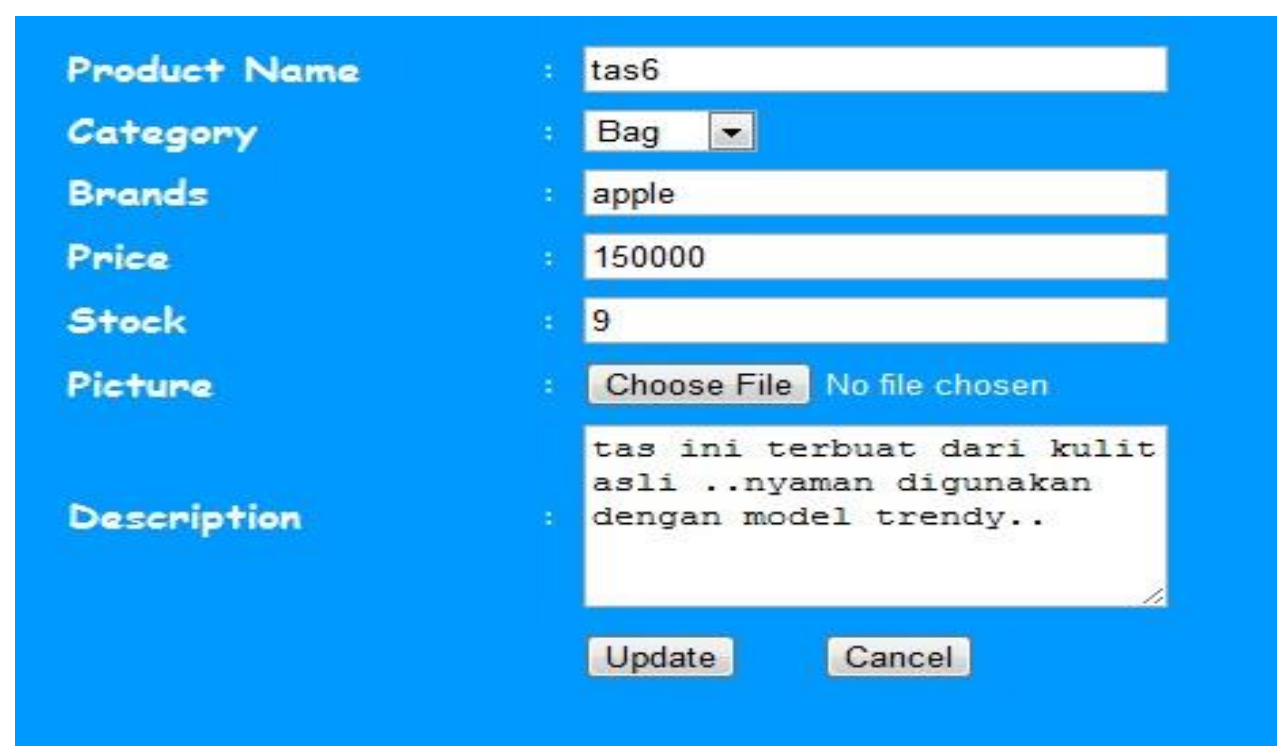

Gambar 14. Input Data Produk

4. Tampilan Proses Pemesanan

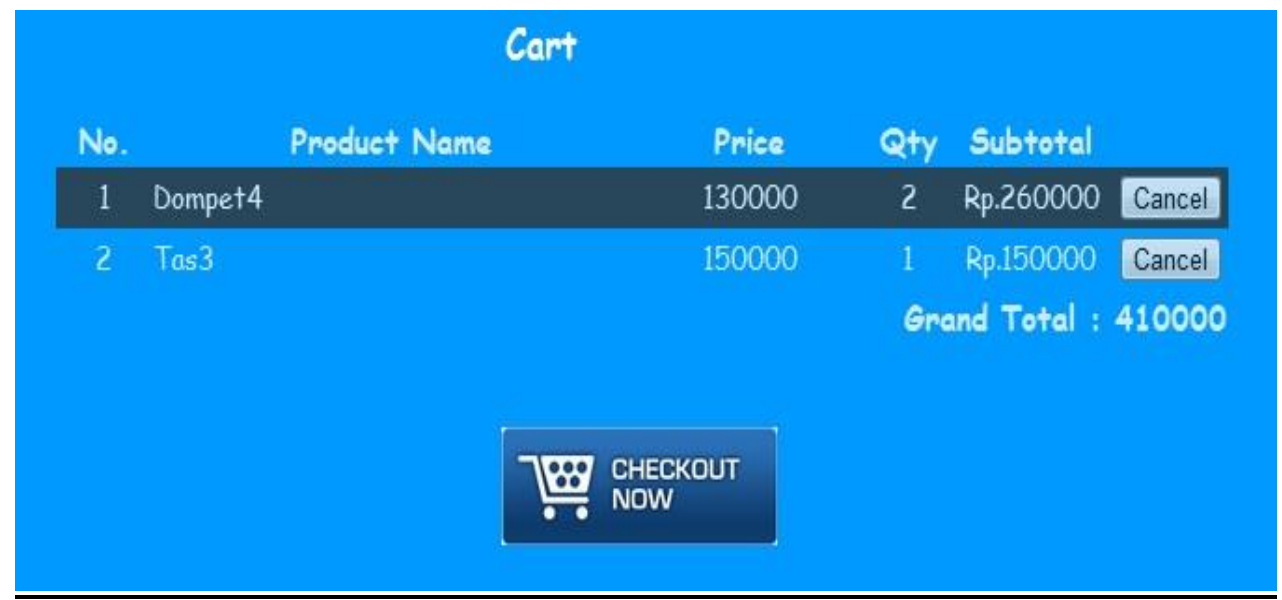

Gambar 15. Tampilan Form Pemesanan

5. Tampilan Proses Penjualan

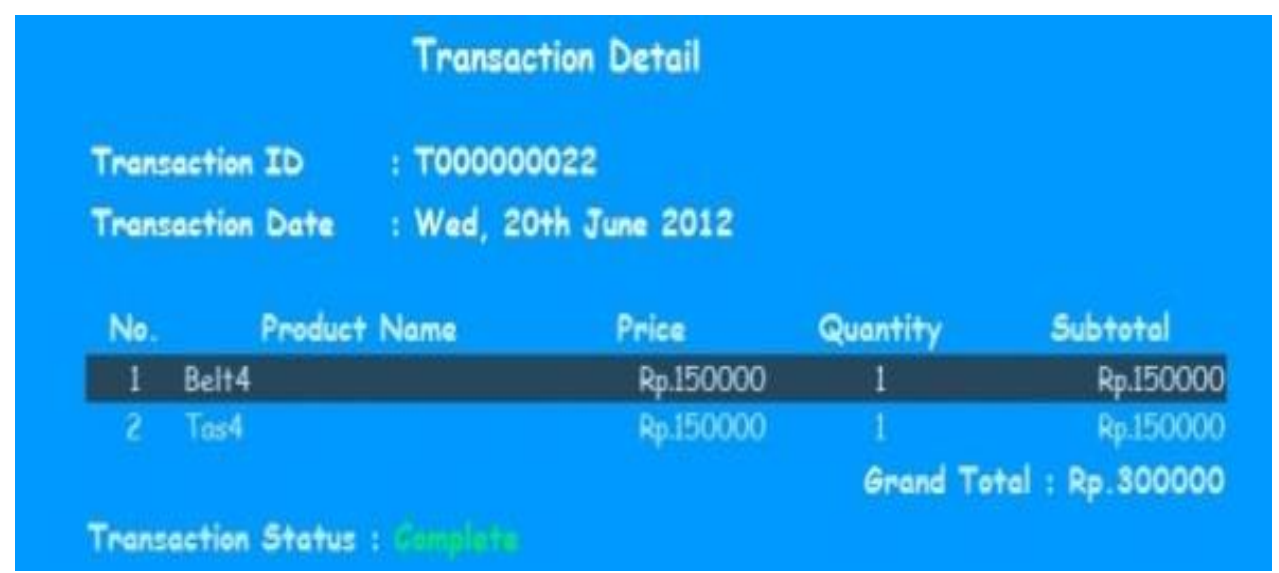

Gambar 16. Tampilan Form Penjualan 


\section{Tampilan Form Stok}

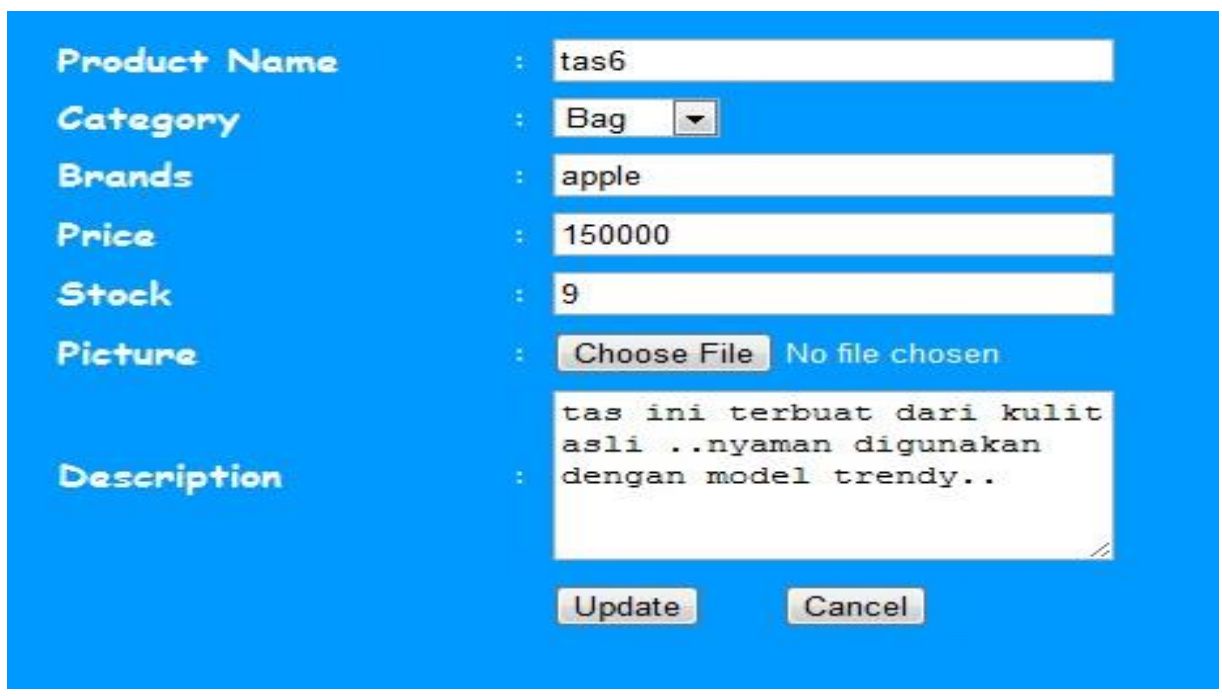

Gambar 17. Tampilan Form Stok

7. Tampilan Form Komplain

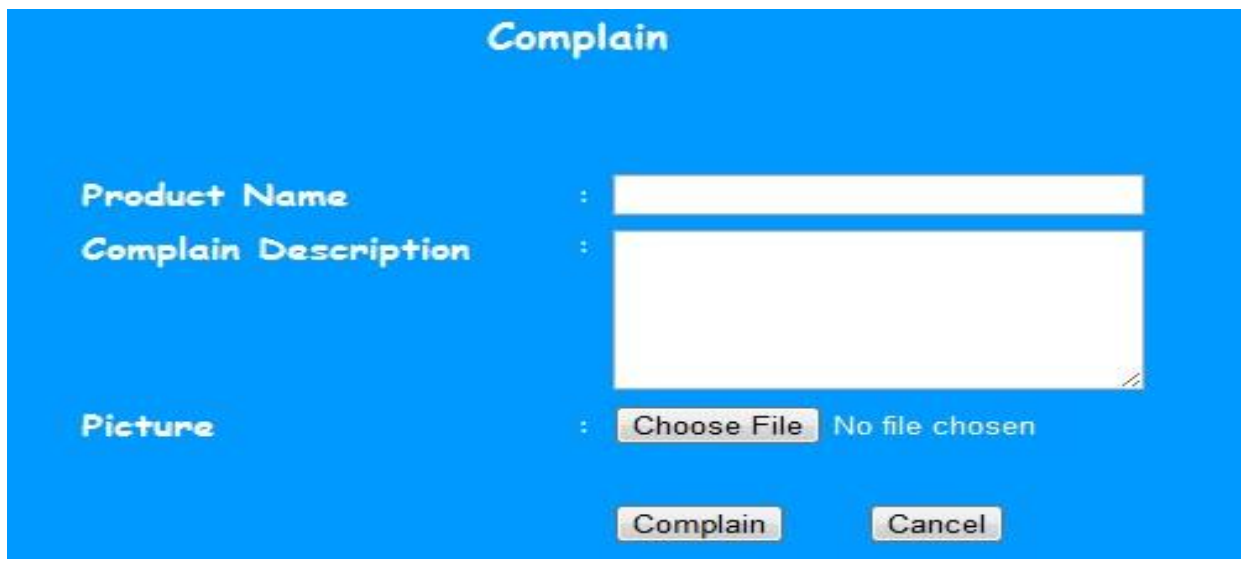

Gambar 18. Tampilan Form Komplain

8. Tampilan Form Testimonial

\section{Testimonial From Our Customer}

\section{Testimonial:}

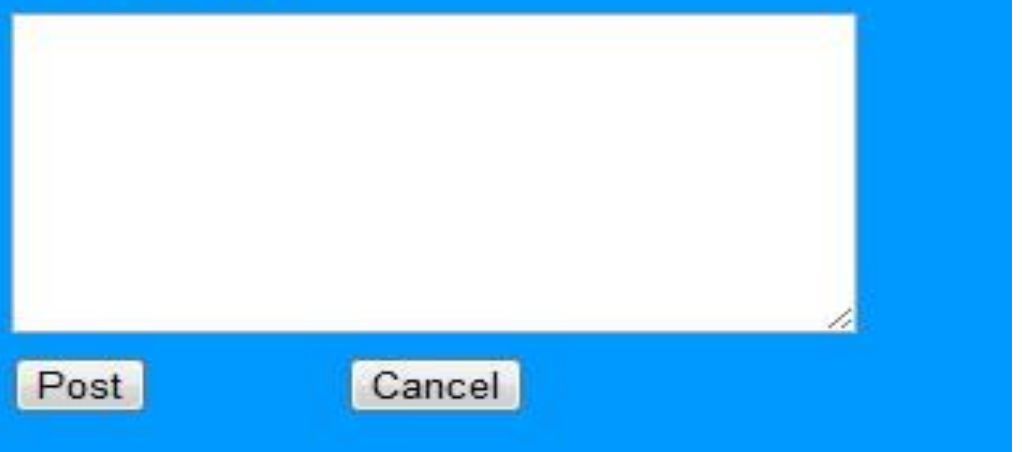

Gambar 19. Tampilan Testimonial 


\title{
9. Laporan
}

\section{Transaction Report}

\author{
Transaction ID : T000000022 \\ Transaction Date : Wed, 20th June 2012

\begin{tabular}{|c|l|r|r|r|}
\hline No. & Product Name & \multicolumn{1}{|c|}{ Price } & \multicolumn{1}{c|}{ Quantity } & \multicolumn{1}{c|}{ Subtotal } \\
\hline 1 & Belt4 & 150000 & 1 & 150000 \\
2 & Tas4 & 150000 & 1 & 150000 \\
\hline
\end{tabular}

Grand Total : Rp.300000,-

Gambar 20. Tampilan Laporan

\section{KESIMPULAN}

Kesimpulan yang dapat diambil dari Aplikasi Penjualan OnLine adalah sebagai berikut:

- Mendapatkan informasi produk dan dapat bertransaksi membeli produk yang sebelumnya harus melakukan registrasi/pendaftaran terlebih dahulu.

- User/Konsumen dapat melakukan komplain dan menulis testimonial

- Pengunjung website yang tidak mendaftar sebagai konsumen, masih dapat melihat produk yang di jual dan juga melihat testimonial yang telah di buat oleh semua customer

\section{DAFTAR PUSTAKA}

1. Anhar. 2010. Panduan Menguasai PHP \& MySQL Secara otodidak. Jakarta; Media kita

2. McLeod, Raymond, Sistem Informasi Manajemen. Edisi 7 Jilid I, Terjemahan Teguh, Hendra Editor Sukardi, Hadi. PT. Prenhallindo, Jakarta

3. Jogiyanto HM, MBA, Akt, PH.D. 2003. Sistem Teknologi Informasi Pendekatan Terintegrasi: Konsep Dasar, Teknologi, Aplikasi, Pengembangan dan Pengolahan. Yogyakarta: Andi Offset

4.

5. Nugroho, Adi. 2006. E-Commerce Memaham Perdagangan Modern DiDunia Maya. Bandung: Informatika

6. Sadeli, Muhammad. 2011. Membuat Toko Online dengan PHP untuk Orang Awam. Palembang: Maxikom

7. Wahana Komputer. 2010. Mendesain Website Dinamis dan Menarik dengan Adobe Dreamweaver CS4. Yogyakarta: Andi Offset

8. Yuhefizar.2008. 10 Jam Menguasai Internet Teknologi dan Aplikasinya. Jakarta; PT.Elex Media Komputindo. 